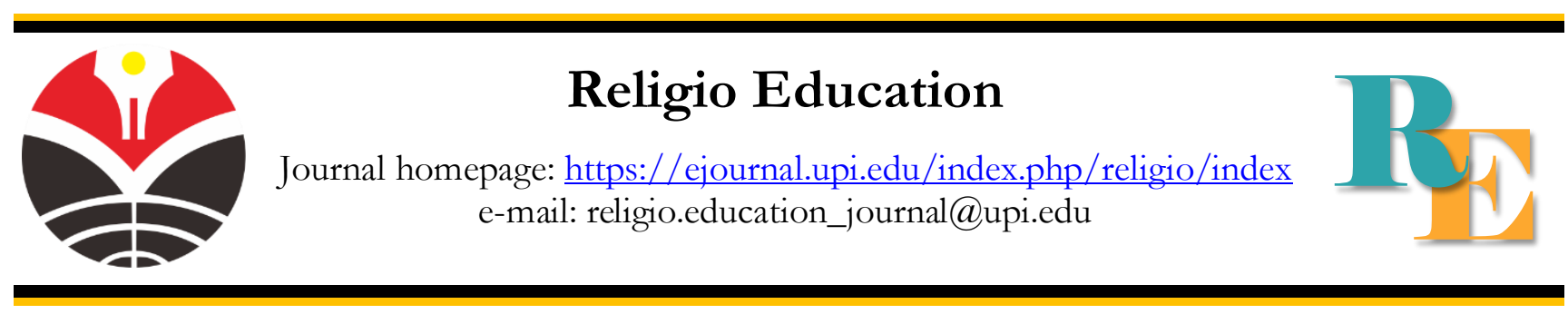

\title{
EXPLORING CULTURAL ACCULTURATION: RITUALS AND SPIRITUAL PRACTICES OF TRADITIONAL CHILDBIRTH IN NANJUNG, BANDUNG REGENCY, WEST JAVA, INDONESIA
}

\author{
Kokom Siti Komariah* \\ Universitas Pendidikan Indonesia, Bandung, Indonesia \\ kokomsitikomariah@upi.edu \\ Mohammad Rindu Fajar Islamy \\ Universitas Pendidikan Indonesia, Bandung, Indonesia \\ fajarislam2000@upi.edu \\ Nurti Budiyanti \\ Universitas Pendidikan Indonesia, Bandung, Indonesia \\ nurtibudiyanti@upi.edu \\ Muhamad Parhan \\ Universitas Pendidikan Indonesia, Bandung, Indonesia. \\ parhan.muhamad@upi.edu \\ *Correspondence: kokomsitikomariah@upi.edu
}

\begin{abstract}
A bstracts
Indonesia is a multicultural country that has so much diversity, among which is the diversity of religions and customs or cultures. Cultural acculturation has a significant impact on the construction of thought and ritual practices carried out by a society. The purpose of this study was to analyze and analyze the practice of traditional child birth carried out by the community in Nanjung Village, Bandung Regency, West Java, Indonesia. The research method used in this study is an ethnographic approach. The author tries to make a visit to the site, then interviewed single information interactively to find the data needed in this study. The data obtained were then analyzed using the theory of acculturation and Islamic religious perspective. The findings prove that the practice of customary childbirth carried out by the perpetrator is a cultural acculturation process. The practice of child birth is at least one way in the context of maximum efforts so that the baby can survive and develop into a pious child
\end{abstract}

Article Info

\begin{tabular}{l}
$\quad$ A r t i c 1 e I n f o \\
\hline Article History: \\
Received 11 Jan 2021 \\
Revised 12 Feb 2021 \\
Accepted 05 Maret 2021 \\
Available online 15 Mei 2021 \\
Keyword: \\
Adat; \\
Childbirth; \\
Nanjung; \\
Ritual; \\
Religious.
\end{tabular}

\section{Introduction}

The phenomenon of cultural acculturation has become one of the hot topics being discussed by intellectuals both nationally and internationally (Ortin et al., 2018; Zhang et al., 
2019). The research developed by Valenzuela and colleagues tries to develop a model strategy for applying the acculturation approach to creating a fit between individuals and the environment.(Valenzuela \& Rogers, 2018). Acculturation has two potential sides, which can contribute positively but can also have negative impacts. Some countries implement strict policies towards immigrants who live in their countries because they are feared to have a negative impact on the process of acculturation brought by them to the midst of society. for example, a research study conducted by Larrañaga and colleagues to analyze the effect of ethnic identity on the traditional Bosque group (native Spanish) and on newcomer groups.(Larrañaga et al., 2016). Furthermore, the research conducted by Stefanidi and friends aims to determine the acculturation, psychological well-being, and adjustment of schools of Pontian teenagers from the former Soviet Union (FSU-Pontians), who are immigrants from the diaspora who live in Greece, compared to immigrants from Albania.(Motti-Stefanidi et al., 2008). In general, researchers believe that acculturation has an impact on behavior and thinking that develops in the community(Archuleta, 2012; Cort, 2010; du Preez \& Govender, 2020; Johnson, 1996; Levinson \& Rodebaugh, 2013; Makarova et al., 2019; Ortin et al., 2018; Reynolds et al., 2012).

Indonesia is a country that has diversity, both ethnicity, culture, religion, language and customs. This certainly has an impact on the process of acculturation and assimilation which has contributed greatly to increasing the diversity and uniqueness that exists in this country. Blended Culture or the amalgamation of cultures is in accordance with the natural and common, especially the current flow of change that is so fast due to technological developments and the flow of globalization. At the level of implementation, people try to accept positive new things based on their frame of mind. Not only the cultural aspect, acculturation can also be transmitted to the process of spreading religion. Like Islam, this religion is viewed by researchers as entering Indonesia through four patterns; first, brought directly from Arabia, second,

In the modern era, it seems that cultural acculturation has entered the realm of childbirth. As happened in Nanjung, Bandung Regency, West Java, Indonesia. The author found a case study where childbirth in the local community was still thick with customs, not being brought to a more modern and sophisticated medical. The practice carried out by Mrs. Aisyah (pseudonym) is unique, including the combination of Islamic theology with elements of Hindu culture, including her belief in her ancestors. In addition, this practice is apparently still believed by some local people even though it is now a very fast modern era.

\section{Methods}

The research method used in this research is by using an ethnographic approach. The author tries to do a direct review of the location which is located in the Nanjung area, Bandung Regency, West Java, Indonesia. Most of Bandung Regency is located between hills and mountains, this certainly has at least an impact on the air condition there. In-depth interviews and observation are two techniques that are combined to explore detailed information regarding the traditional labor process there. The survey was conducted twice, each interview lasting approximately one hour.

The primary informant source in this research study is Aisyah's mother (pseudonym), a housewife who has daily duties to care for her children. The reason why the research is only focused on interviews with her, not on others such as her patients or the local community, is because from the beginning the author wanted to try to develop a theology of belief that underlies her practice of childbirth rituals and trace the flow of stages of the labor process 
carried out by her. According to the author, this is what the author feels, only a single informant is sufficient without interviewing others.

In helping to maintain the data obtained, the author tries to save the results of the interview by recording by a recording device that is on the cellphone. The results of the recording, the author tries to review and then analyze the various findings obtained in the field. This research will focus on answering several research problems related to cultural and religious discourse among them are:

a. How is the Religious Theology covering the cultural practices of childbirth in Nanjung Regency by Mrs. Aisyah?

b. What are the stages carried out by Mrs. Aisyah in order to carry out her cultural practice of childbirth?

c. What is the relevance of the cultural birth carried out by Mrs. Aisyah with Religious Discourses that exist at national and international levels?

Besides trying to explore the answers to the three problems above, this research seeks to examine whether the cultural practices of childbirth practiced by Mrs. Aisyah are relevant to religious phenomena, research studies, and theories developed not only by intellectuals from Indonesia, but also intellectuals who come from abroad.

\section{Results and Discussion}

\section{Demographics of Nanjung, Bandung Regency, West Java, Indonesia}

Bandung Regency geographically has a land area of about 176,238.67 hectares. This district consists of thirty one sub-districts which are distributed among 270 villages. The thirtyone districts namely Ciwidey, Rancabali, Pasirjambu, Ciamung, Pangalengan, Kertasari, Pacet, Ibun, Paseh, Cikancung, Cicalengka, Nagreg, Rancaekek, Majalaya, Solokanjeruk, Ciparay, Baleendah, Arjasari, Banjaran, Cangkuang, Pameungpeuk, Katapang, Soreang, Kutawaringin, Margaasih, Dayeuhkolot, Bojongsoang, Cileunyi, Cilengkrang, and Cimenyan. There are two main commodities developed in Bandung Regency, namely the agricultural sector and the industrial processing sector. Reporting from the results of the consolidation of the Ministry of Home Affairs in the first semester of 2017, it was recorded that the population living in the Bandung Regency area was a total of 3,522,724 with a division of 1,802,064 men. while women were 1,720,660. The components of success in human development can at least be seen from the achievements of the Human Development Index (HDI). There are three main indicators, namely knowledge, life opportunity (health), and life feasibility (purchasing power). The success of education can be a mirror for the non-physical conditions of society. Health and purchasing power can be used as benchmarks for the physical condition of humans. In 2014, Bandung district obtained an HDI score of 75.69. The HDI acquisition has increased compared to the previous year. The success of education can be a mirror for the non-physical conditions of society. Health and purchasing power can be used as benchmarks for the physical condition of humans. In 2014, Bandung district obtained an HDI score of 75.69. This HDI acquisition increased compared to the previous year. The success of education can be a mirror for the nonphysical conditions of society. Health and purchasing power can be used as benchmarks for the physical condition of humans. In 2014, Bandung district obtained an HDI score of 75.69. The HDI acquisition has increased compared to the previous year. 
Regarding cultural and social aspects, Bandung Regency is one of the leading districts in maintaining regional identity and cultural values from the influence of the rapid and significant flow of globalization. Art and culture are among the top priorities for office holders so that they do not fade. One indicator of the strengthening of arts and culture in this district is the preservation and sharpness of the literacy of the people of Bandung Regency towards cultural values and the use of Sundanese Regional Language. The characteristics of the community in this area are so thick with strong morality in terms of hard work, mutual cooperation, appreciation of culture and language.

Tourism is one of the leading fields developed by the local government. This sector has tremendous potential due to the geographical location of Bandung Regency which is very likely to be maximized. Among the leading tourism spots that are often used as recreational destinations by the Indonesian people, namely:

a. Natural Tourism Areas: Mount Patuha / Kawah Putih, Cimanggu, Situ Patengan, Curug Cisabuk, Cibuni Crater, Walini, Ranca Upas, Mount Puntang, Lamajang Rafting, Cibolang, Punceling, Situ Cileunca, Mount Papandayan Crater, Palayangan Rafting, Eti Curug, and so on.

b. Cultural Tourism Area, including Mount Padang (Ciwidey District), Cikondang traditional house, Black House (Pangalengan District), Bumi Alit Traditional House (Banjaran District), Mahmud Village Site (Margaasih District), Karang Gantung Site (Pacet District), Bojongmenje Site (Rancaekek District), Jelekong Arts Center (Baleendah District), Cimenyan Arts Center (Cimenyan District), Craft Center (Pasirjambu District), Benjang Arts Tourism Center (Cileunyi District).

c. Agro Tourism Areas, including: Strawberry Agro Tourism: Pasirjambu District, Rancabali District, Ciwidey District, Pacet District, Arjasari District, Pangalengan District, Ibun District, Paseh District.

\section{Theology of Indigenous Cultural Practices of Childbirth}

The theology or belief that is owned by a person is one essential component that encourages and motivates to make a certain effort. The birth of a baby is a dream that is expected by a harmonious family couple. A baby will have a good period of emotional development when it comes to loving care. Good and correct parenting patterns and connectivity that exists between a mother and her baby contribute greatly to improving the emotional development of the baby (Rochel, 2012; Silva \& Porto, 2016). In the midst of modernity, it seems that some people still have a strong theology that adheres to the traditions of their ancestors. Where this group prefers an alternative path that is built on the beliefs of their ancestors, which is to hand over the delivery procession to certain people outside of a medical expert (midwife), namely someone who is believed to have strength and strength in the process of delivering babies.

This is what also happened to Mrs. Aisyah (a pseudonym), where in her customary practice of childbirth at least the author found several beliefs which would certainly have an impact on the construction of thoughts and understanding that bind her practical activities. In the interview, Mrs. Aisyah said:

"Babies who are cared for by mothers (Mrs. Aisyah), usually do not fuss, do not cry, even when they are adults, they develop into pious children. In principle, the delivery that you do is to pray for the baby and its parents to be given safety both when the baby is born and after growing up. " 
In general, affection is one thing that a baby needs (Parhan \& Kurniawan, 2020). According to Mahler, an expert states that in normal development the real separation between the baby and the mother can have an impact on her childish feelings and serve as legitimacy for her as a separate person. This opinion is at least in line with the research conducted by Lemos and his friends, where he proved the relevance of child development and how parents can pay attention to their babies (Lemos et al., 2019). At least according to the author, Mrs. Aisyah can fill this void, so it is natural that the baby who is cared for by her at least has good development and there are not many problems such as crying, fussiness and others. In general, affection is indeed the main measure, whether it is done by the mother or others, the baby will respond to this affection positively. Islam teaches the principles of educating children in accordance with the teachings given by the Prophet Muhammad as described by Muhammad Rowwas, Professor of Religious Sciences, namely the principles of Mura'āt Al-Furūq Al-Fardiyyah respect for the individual characteristics of each (Rawwas, 1988). This is what Mother Aisyah might do, with her caress and affection the baby grows and develops well social interaction is an aspect of concern for Islam (Al-Arefe, 2011; As-Shalabi, 2008).

Furthermore, in contrast to the majority of birth centers that have developed both in cities and villages, Mrs. Aisyah in practice does not provide a certain nominal rate. He also explained the importance of the principle of benefit for Together:

"In doing this practice, you never ask for a certain fee, you just leave it to each person. For Mother (Mrs. Aisyah), being blessed and beneficial to others has become a noble task"

Mrs. Aisyah really holds the Theology of Benefit, which is why she never gives special rates for her practice. Even if there really is a family that is not kissing, it is free of charge. Gratitude is an attitude that must be put forward in order to communicate with Allah SW'T. Islam teaches its people to always provide benefits to others (Al-Qaḥtānī, 2006). This is confirmed in a hadith:

"The best of humans is the most beneficial for others"

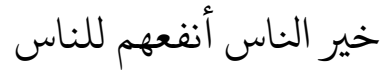

Another spiritual value that the author found in the field is the scientific ecosystem that is connected between him and his ancestors. Ibu Aisyah believes that scientific transmission is a common thing and exists, not only in the world of her childbirth, but in terms of characteristics. this can be seen from how he explains the origin of his skills:

"The skills you have at least get them from your ancestors, so you already have a lineage in this skill. Usually some Javanese people already know this ritual, so without being asked they will immediately carry out this tradition "

Genetics is one of the factors that support one's talent. According to Sheh Seow Wah, an expert in the field of management, his book entitled Chinese Leadership From the Classical to the Modern Age proves the existence of the power of hereditary factors in several leadership cases that occurred in China. In several works of Muslim intellectuals when exploring the history of the personality of Rosulullah saw, at least heredity is seen as a factor that plays an 
important role in the strength of the positive character possessed by Rosulullah saw (Al-Siba'i, 1985; Ghadhban, 1992). Although heredity has a role, the management system is another important factor in creating success in a management culture (Kargün, 2015; Kozak \& Uca, 2008).

\section{Procedures and Stages of Traditional Childbirth}

In a ritual, of course, there are several stages that must be carried out, then several conditions must be fulfilled by the baby's family who will carry out the birth ritual. In accordance with the provisions that have been determined. When the baby's parents give birth, the placenta is cut off to be buried using a jug (made of clay), then the baby is swaddled and the call to prayer is performed. Then after a week has passed, the mother of the baby is massaged so that her veins are not stiff after childbirth and her milk production can be smooth due to the massage. Parents of the baby must prepare several conditions for the birth of the baby, the following conditions: tray, nyiru, rice, turmeric, garlic, onion, panglai, three glasses of water, black coffee, and tea, stick, flowers seven faces and scissors.

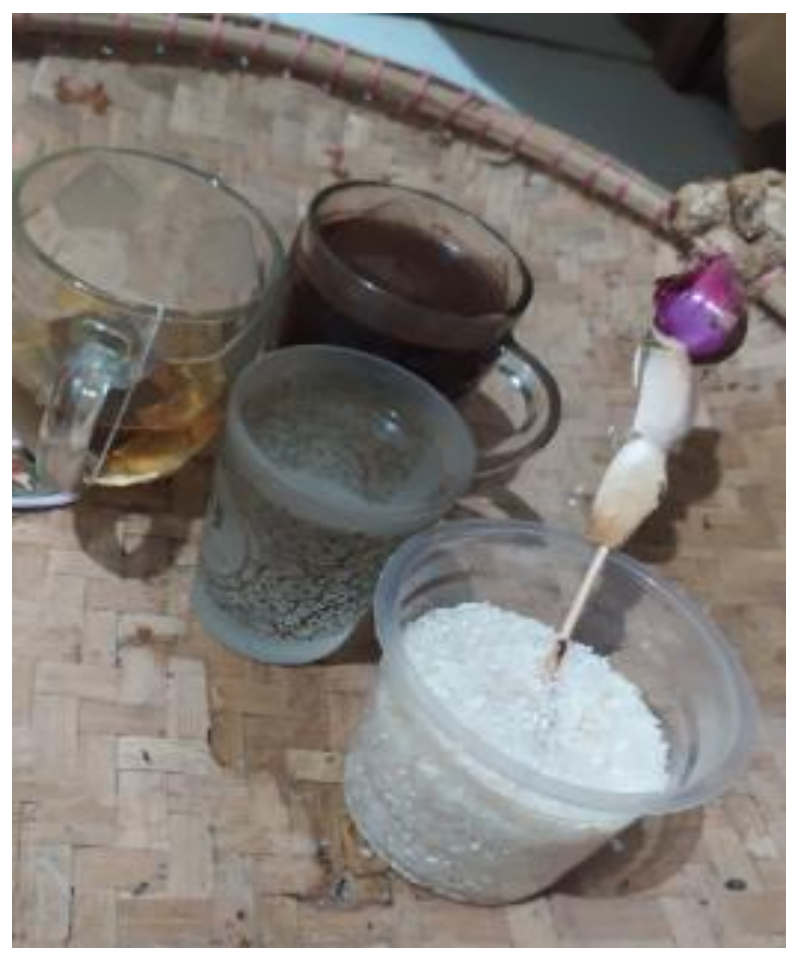

Figure 1. Tools needed in Labor

The conditions above must be carried out in accordance with the stipulated conditions, then the baby is given a rope bracelet whose function is to be saved with his parents, then the baby has his hair shaved and bathed with seven forms of flowers. Then the baby is prayed for with prayers taken from the prayer book of promising, yasin, and rejecting reinforcements. Because by performing this ritual it is hoped that the baby will not be fussy and cry, then at night he will be calmer. Aisyah's efforts to pray for her are very useful and can even turn the children she takes care of into pious and pious children and devoted to both parents.

In Ibu Aisyah's opinion, the ritual of childbirth cannot be practiced by just anyone. In his belief, this practice can only be done by certain people, one of them is himself. The reason behind it is because he has a talent that has existed since birth from a bloodline that has been 
passed down from generation to generation from his ancestors. According to him, this theology is still valid and exists in several areas, one of which is Java. There the local people are still thick with this kind of ritual culture, and the majority of them believe this customary birth practice can save the parents of babies and their babies from being in danger.

\section{Religious Polysemy and Cultural Rituals of Childbirth}

The phenomenon of local customary childbirth practices carried out by Mrs. Aisyah in the Nanjung area, Bandung Regency, West Java, Indonesia is similar to a research study conducted by Ziad Munson in her research entitled When A Funeral is Just not a Funeral: The Layered Meaning of Everyday Action in essence is to look at the extent to which one's experience of religiosity is awakened from pure religious activity without the intervention of other interests. Munson gave a name for a discourse like this with the term polysemic which is interpreted by the overlapping of religious activities with other activities such as social, political and other activities, so that there is no agreement on the categorization of which experiences or activities are purely religious areas, which are outside religion. According to the author's analysis, Munson's findings related to this phenomenon are actually found in the world of modernity. Religion is often politicized as a force to achieve a certain goal, even this phenomenon is reduced to religious rituals carried out by contemporary society in its practical order. The author takes for example, contemporary tasawwuf movements where many international research studies prove this. Intellectual Simon Stjernholm in his scientific study published in the journal of Islamic Law and Culture states that the Sufis in London combine religious activities with politics to achieve certain goals. The Sufi Muslim Council (The Sufi Muslim Council) was accused of carrying out a terrorist attack in London in 2005 so that the government had time to interrogate their da'wah activities (Stjernholm, 2010). although in the end they proved that these extremist actions were not a movement they were carrying out, this still shows that sometimes the external community has not standardized to sort out which religious groups are purely interpreting religious da'wah. Then there is the Sufistic movement in African countries, a study conducted by Muhammed Haron in which he sees the phenomenon of competition among tariqah groups to seize spiritual public space in Africa. This study focuses on studying the Sufistic da'wah movement of the Chistiyyah, Murabitun, Qadriyyah, Alawiyyah, and Naqshabandi groups (Haron, 2005). Contemporary sufic movements are seen by scientists and sociologists as often politicized and used for certain movements such as politics and da'wah which according to Munson this phenomenon is in line with the concept of polysemy (Arai, 2007; Dang, 2017; Degorge, 2000; GULAY, 2007; Josefsson et al., 2017; Laffan, 2011; Milani \& Adrahtas, 2018; Rehman \& Lund-Thomsen, 2014; Rytter, 2016; Rywkin, 1991; Salvatore, 2018).

The author sees that there are also global phenomena visible to the naked eye as negative and even destructive activities, but it could be that from the perspective of the perpetrators this is a sacred and valuable religious activity. Jihad activities can be used as a tool to measure the level of truth of this phenomenon. Scientists and even the majority Muslim scholars view the activities of Jihadi Salafi carried out by extremist groups such as Al-Qaeda which tend to display hard struggle movements so that the global community is seen more as a movement of radicalism, anarchism, and even terrorism (Parhan et al., 2020). This cynical and negative view is at least supported by international research studies such as that of Mehmet Orhan where he proved that the radical Al-Qaeda movement was a movement that first emerged in the 2000s in Turkey. This group, according to Orhan, built a small autonomous movement outside the power structure and carried out bigger social and political actions in several cities such as Bingol in Kurdish. Orhan concluded that Al-Qaeda is a new form of radicalism with a focus on local and global socialization instruments that have resulted in organizational, strategic, axiological and teleological divisions with traditional Islamic movements in the region (Orhan, 2010). In line 
with Orhan, Ric in his study found the relevance of the contextualism of radicalism of Islamic extremism groups between Egypt and Tunisia (Neo, 2019). Jihad activities that present a form of "violent" action are still largely considered radical acts (Battiston, 2019; Hasanov, 2005; Latham, 1999; Miller, 2009; Ronen, 2007; Schofield, 2004; Varouxakis, 2004; Yang et al., 2014). Even though the contemporary Jihad movement was judged as a radical movement, for the perpetrators it was still believed to be part of the struggle movement in the path of God. This is as believed by extremist groups in Indonesia who were willing to commit suicide bombings during the Bali bombings in 2002. According to their accounts published in the mass media, the suicide bombing they carried out in their belief was not an act of deviation, but rather as an act. holy part of the commandment of God.

The polysemic phenomenon has actually become the main concern of Islamic scholars since the Prophet Muhammad was sent. Perhaps the authors see this phenomenon as an integral part of Islamic studies related to intention. The author sees that religion is a way of life both in the world and in the hereafter, so that the consequence is that all human life activities and all their aspects such as politics, economy, preaching, culture, social, and others cannot be separated from religion. In fact, the authors disagree when there is a discourse echoed by Western groups with the term secularization, namely separating religion from worldly things. This is a philosophical thought that is not taught by religion. Many verses of the Koran and Hadith emphasize the relationship between religion and all aspects of human life. The author sees that Munson's concept regarding polysemy of activity is actually a natural thing because previously religion is the center of activity that is distributed to certain areas such as politics and so on. To standardize which religious activities are, which ones are not returned to the concept of divine purpose or with the familiar name, namely intention. If a person's intention is to act sincerely according to God and according to religious rules, then this does not violate. This concept has been agreed upon by Muslim scholars as in his works The author sees that Munson's concept regarding polysemy of activity is actually a natural thing because previously religion is the center of activity that is distributed to certain areas such as politics and so on. To standardize which religious activities are, which ones are not returned to the concept of divine purpose or with the familiar name, namely intention. If a person's intention is to act sincerely according to God and according to religious rules, then this does not violate.

This concept has been agreed upon by Muslim scholars as in his works The author sees that Munson's concept regarding polysemy of activity is actually a natural thing because previously religion is the center of activity that is distributed to certain areas such as politics and so on. To standardize which religious activities are, which ones are not returned to the concept of divine purpose or with the familiar name, namely intention. If a person's intention is to act sincerely according to God and according to religious rules, then this does not violate. This concept has been agreed upon by Muslim scholars as in his works which ones are not then returned to the concept of divine purpose or with the familiar name, namely intention. If a person's intention is to act sincerely according to God and according to religious rules, then this does not violate. This concept has been agreed upon by Muslim scholars as in his works which ones are not then returned to the concept of divine purpose or with the familiar name, namely intention. If a person's intention is to act sincerely according to God and according to religious rules, then this does not violate. This concept has been agreed upon by Muslim scholars as in his works(Al-Būțī, 1973; Al-Da'as, 1989; Al-Juhni, nd; Al-Laham, 1956; Al-Qardhawi, 1993, 2007; As-Sya'rawi, 1998; Azizah, 2001; Nasir Muhammadi Muhammad Jad, 2009).

\section{Conclusion}

The practice of traditional childbirth carried out by Mrs. Aisyah (a pseudonym) in the Nanjung area, Bandung Regency, West Java, is a portrait of how the acculturation process seems to have 
an impact on the ritual level of the local community. The theology that covers the practice of traditional childbirth is the belief that this ritual can keep parents and babies away from harm, the belief that their expertise is only owned by special people because it requires heredity, and the belief in the principle of benefit to society. in practice, certain preparations and materials are needed to facilitate the labor process. In the end, this phenomenon that occurs, is considered by the author to have similarities with the ideas offered by Ziad Munson regarding his polysemy theory where there is an overlap between religious activities and several other aspects such as social politics, as well as economics. So that there is no standardization where pure practices are born from religion, which are activities that are purely non-religious.

\section{References}

\section{Books}

Al-Arefe, M. bin A. (2011). Istamti' Bi Hayātika Funūn At-Ta'ämul Ma'a An-Nās fì Drilli As-Sìrah An-Nabawiyyah. Saudi Arabia: Sarikah Muslim.

Al-Būțī, M. S. R. (1973). Dhawabith Al-Mashlabah fi Al-Sya'riah Al-Islamiyyah (p. 466). Muassasah Ar-Risalah.

Al-Da'as, I. 'Ubayd. (1989). Al-Qawa'd Al-Fiqhiyyah ma'a Al-Syarb Al-Mujaz (p. 128). Dar AtTirmidzi.

Al-Juhni, M. bin H. (n.d.). Al-Mausü'ah Al-Muyassarah fì Al-Adyān wa Al-Madz̃äbib wa Al-Abz̄āb Al-Mu'ashirah. Maktabah Al-Mulk Fahd Al-Wathaniyyah.

Al-Laham, A. I. (1956). Al-Qawä'id wa Al-Fawäid Al-Ushüliyyah Wa Mà Yata'allaq Bìā min AlAbkàm Al-Far'iyyah (p. 347). As-Sunnah Al-Muhammadiyyah.

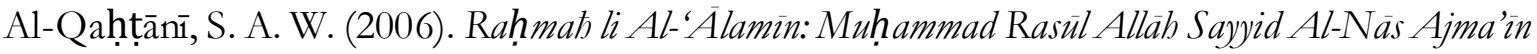

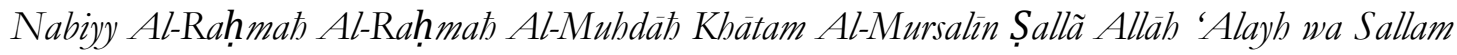
(p. 512). Maktabah Al-Mulk Fahd Al-Wathaniyyah.

Al-Qardhawi, Y. (2007). Ushül Al-'Amal Al-Khairì Fì Al-Islàm Fì Dhani An-Nushüsh Wa AlMaqāsid As-Syarìah. Cairo: Dar As-Syuruq.

Al-Siba'i, M. (1985). Al-Sirah Al-Nabawiyah Durus wa 'Ibar (p. 194). Al-Maktab Al-Islami.

Arai, K. (2007). Combining Innovation and Emotion in the Modernization of Sufi Orders in Contemporary Egypt. Critique: Critical Middle Eastern Studies, 16(2), 155-169. https://doi.org/10.1080/10669920701378879

As-Shalabi, A. M. (2008). As-Sirah An-Nabiwiyyah Ard Waqa'i Wa Tablil Abdats (p. 934). Dar AlMa'rifah.

As-Sya'rawi, M. M. (1998). Al-Ghaib (p. 128). Maktabah Al-Sya'rawi Al-Islamiyyah.

Azizah. (2001). Al-Qawäìd wa Ad-Dhawäbith Al-Fiqhiyyah Al-Mustakblashah min Kitäb Ushül AlFatāya Li Al-Imām Ibnu Hārits Al-Khusyñi. Jami'ah Al-Jazairi.

Ghadhban, M. M. (1992). Figh As-Sirah An-Nabawiyyah (p. 752). Jami'ah Ummur Qura.

Rawwas, M. (1988). Dirasah Tabliliyyah Li Syabshiyati Ar-Rasul Mubammad (pp. 1-303). Dar AnNafais. 


\section{Journal}

Archuleta, A. J. (2012). Hispanic Acculturation Index: Advancing Measurement in Acculturation. Journal of Human Behavior in the Social Environment, 22(3), 297-318. https://doi.org/10.1080/10911359.2012.655593

Battiston, S. (2019). Migrant radicalism and activism in australia: The transnational experience of Pierina Pirisi. Journal of Australian Studies, 43(2), 160-173. https://doi.org/10.1080/14443058.2019.1611621

Cort, D. A. (2010). What happened to familial acculturation? Ethnic and Racial Studies, 33(2), 313335. https://doi.org/10.1080/01419870903100161

Dang, C. T. N. (2017). Erotics, poetics, politics: the spheres of action of Senegalese Sufi voices. Ethnomusicology Forum, 26(3), 349-372. https://doi.org/10.1080/17411912.2018.1426995

Degorge, B. (2000). Millennial Islam in Africa: Sufi Politics in the Sudan. The European Legacy, 5(2), 195-206. https://doi.org/10.1080/10848770050013637

du Preez, E. A., \& Govender, L. K. (2020). Travelling to the Motherland: relating acculturation to diaspora tourism experiences. Anatolia, 31(2), 197-210. https://doi.org/10.1080/13032917.2020.1747220

GULAY, E. N. (2007). The Gülen Phenomenon: A Neo-Sufi Challenge to Turkey's Rival Elite? Critique: Critical Middle Eastern Studies, 16(1), 37-61. https://doi.org/10.1080/10669920601148604

Haron, M. (2005). Da'wah movements and Sufi tariqahs: Competing for spiritual spaces in contemporary south(ern) Africa . Journal of Muslim Minority Affairs, 25(2), 261-285. https://doi.org/10.1080/13602000500114157

Hasanov, E. (2005). Religious and national radicalism in Middle-Eastern countries: A psychoanalytical point of view. International Forum of Psychoanalysis, 14(2), 120-122. https://doi.org/10.1080/08037060510043832

Johnson, M. A. (1996). Latinas and television in the United States: Relationships among genre identification, acculturation, and acculturation stress. Howard Journal of Communications, 7(4), 289-313. https://doi.org/10.1080/10646179609361733

Josefsson, T., Nilsson, M., \& Borell, K. (2017). Muslims Opposing Violent Radicalism and Extremism: Strategies of Swedish Sufi Communities. Journal of Muslim Minority Affairs, 37(2), 183-195. https://doi.org/10.1080/13602004.2017.1339498

Kargün, M. (2015). Managers' perception of organizational culture and organizational communication. Anthropologist, $22(1), \quad 44-49$. https://doi.org/10.1080/09720073.2015.11891855

Kozak, M. A., \& Uca, S. (2008). Effective factors in the constitution of leadership styles: A study of Turkish hotel managers. Anatolia, 19(1), 117-134. https://doi.org/10.1080/13032917.2008.9687057

Laffan, M. (2011). The makings of Indonesian Islam: Orientalism and the narration of a sufi past. The Makings of Indonesian Islam: Orientalism and the Narration of a Sufi Past, 19(5), 1-301. https://doi.org/10.1080/10848770.2014.943520 
Larrañaga, N., Garcia, I., Azurmendi, M. J., \& Bourhis, R. (2016). Identity and acculturation: interethnic relations in the Basque Autonomous Community. Journal of Multilingual and Multicultural Development, 37(2), 131-149. https://doi.org/10.1080/01434632.2015.1044996

Latham, J. (1999). The political and the personal: The radicalism of Sophia Chichester and Georgiana Fletcher Welch. Women's History Review, 8(3), 469-487. https://doi.org/10.1080/09612029900200216

Lemos, E. de J. S., Silva, C. V., \& Pedroso, J. da S. (2019). Observing the emotional development of a baby at home and in a nursery using ester Bick's infant observation method. Early Child Development and Care, O(0), 1-10. https://doi.org/10.1080/03004430.2019.1625895

Levinson, C. A., \& Rodebaugh, T. L. (2013). Anxiety, self-discrepancy, and regulatory focus theory: Acculturation matters. Anxiety, Stress and Coping, 26(2), 171-186. https://doi.org/10.1080/10615806.2012.659728

Makarova, E., 't Gilde, J., \& Birman, D. (2019). Teachers as risk and resource factors in minority students' school adjustment: an integrative review of qualitative research on acculturation. Intercultural Education, 30(5), 448-477. https:/ / doi.org/10.1080/14675986.2019.1586212

Milani, M., \& Adrahtas, V. (2018). Modern talking: Sufi socio-political discourse. Journal of Religious and Political Practice, 4(2), 175-194. https://doi.org/10.1080/20566093.2018.1439813

Miller, A. (2009). Pragmatic radicalism: An autoethnographic perspective on pre-service teaching. Teaching and Teacher Education, 25(6), 909-916. https://doi.org/10.1016/j.tate.2009.01.012

Motti-Stefanidi, F., Pavlopoulos, V., Obradovic, J., \& Masten, A. S. (2008). Acculturation and adaptation of immigrant adolescents in Greek urban schools. International Journal of Psychology, 43(1), 45-58. https://doi.org/10.1080/00207590701804412

Nasir Muhammadi Muhammad Jad. (2009). al-Ta'amul Ma'a Ghayr al-Muslimin fi 'Abd al-Nabawi.

Neo, R. (2019). The Jihad post-Arab Spring: Contextualising Islamic radicalism in Egypt and Tunisia. African Security Review, 28(2), 95-109. https://doi.org/10.1080/10246029.2019.1679651

Orhan, M. (2010). Al-Qaeda: Analysis of the emergence, radicalism, and violence of a jihadist action group in Turkey. Turkish Studies, 11(2), 143-161. https://doi.org/10.1080/14683849.2010.483846

Ortin, A., Miranda, R., Polanco-Roman, L., \& Shaffer, D. (2018). Parent-Adolescent Acculturation Gap and Suicidal Ideation among Adolescents from an Emergency Department. Archives of Suicide Research, 22(4), 529-541. https://doi.org/10.1080/13811118.2017.1372828

Parhan, M., Islamy, M. R. F., Budiyanti, N., Nugraha, R. H., \& Hyangsewu, P. (2020). Responding to Islamophobia by Internalizing the Value of Islam Rahmatan Lil Alamin through Using the Media. Islam Realitas: Journal of Islamic and Social Studies, 6(2), 139-152. https://doi.org/http://dx.doi.org/10.30983/islam_realitas.v6i2.3695

Parhan, M., \& Kurniawan, D. P. D. (2020). Aktualisasi Peran Ibu Sebagai Madrasah Pertama Dan Utama Bagi Anak Di Era 4.0. JMIE (Journal of Madrasah Ibtidaiyah Education), 4(2), 157. 
https://doi.org/10.32934/jmie.v4i2.193

Rehman, U., \& Lund-Thomsen, P. (2014). Social support at a Sufi lodge in Punjab, Pakistan. Contemporary South Asia, 22(4), 377-388. https://doi.org/10.1080/09584935.2014.963515

Reynolds, A. L., Sodano, S. M., Ecklund, T. R., \& Guyker, W. (2012). Dimensions of acculturation in native American College Students. Measurement and Evaluation in Counseling and Development, 45(2), 101-112. https://doi.org/10.1177/0748175611428330

Rochel. (2012). A importância da relação mãe-bebê no primeiro ano de vida como fator determinante para um desenvolvimento emocional satisfatório [The importance of mother-baby relationship in the first year of life as a determining factor for a thorough emotional develop. Revista Da Faculdade de Ciências Médicas de Sorrcaba, 14(2), 82-83.

Ronen, Y. (2007). Between the Mahdiyya and the Muslim brotherhood: Continuity and change in Islamic radicalism in Sudan. Journal of North African Studies, 12(1), 1-18. https://doi.org/10.1080/13629380601099427

Rytter, M. (2016). Burger Jihad: Fatal attractions at a Sufi lodge in Pakistan. Journal of Muslim Minority Affairs, 36(1), 46-61. https://doi.org/10.1080/13602004.2016.1147154

Rywkin, M. (1991). The Communist Party and the Sufi Tariqat in the Checheno-Ingush Republic. Central Asian Survey, 10(1-2), 133-145. https://doi.org/10.1080/02634939108400740

Salvatore, A. (2018). Sufi articulations of civility, globality, and sovereignty. Journal of Religious and Political Practice, 4(2), 156-174. https://doi.org/10.1080/20566093.2018.1439808

Schofield, P. (2004). Jeremy Bentham, the French Revolution and political radicalism. History of $\begin{array}{llll}\text { European } & \text { Ideas, } & 30(4 & \text { SPEC.ISS.), }\end{array}$ https://doi.org/10.1016/j.histeuroideas.2003.11.019

Silva, \& Porto. (2016). A Importância da Interação Mãe-Bebê [The importance of Mother-infant Interaction]. Ensaios e Ciências: Ciências Biológica, Agrárias e Da Saúde, 20(2), 73-78. https://doi.org/doi:10.17921/1415-6938. 2016v20n2p73-78

Stjernholm, S. (2010). Sufi politics in Britain: the Sufi Muslim Council and the 'silent majority' of Muslims. Journal of Islamic Law and Culture, 12(3), 215-226. https://doi.org/10.1080/1528817x.2010.618025

Valenzuela, M. A., \& Rogers, S. E. (2018). Strategizing personality traits: an acculturation approach to person-environment fit and expatriate adjustment. International Journal of Human Resource Management, O(0), 1-29. https://doi.org/10.1080/09585192.2018.1526201

Varouxakis, G. (2004). French radicalism through the eyes of John Stuart Mill. History of European Ideas, 30(4 SPEC.ISS.), 433-461. https://doi.org/10.1016/j.histeuroideas.2003.11.018

Yang, D. L., Xu, H., \& Tao, R. (2014). A Tragedy of the Nomenklatura? Career incentives, political loyalty and political radicalism during China's Great Leap Forward. Journal of Contemporary China, 23(89), 864-883. https://doi.org/10.1080/13603116.2014.882560

Zhang, Q., Liu, R., Diggs, L. A., Wang, Y., \& Ling, L. (2019). Does acculturation affect the dietary intakes and body weight status of children of immigrants in the U.S. and other developed countries? A systematic review. Ethnicity and Health, 24(1), 73-93. https://doi.org/10.1080/13557858.2017.1315365 